\title{
Sex differences in lower urinary tract biology and physiology
}

\author{
Benjamin Abelson ${ }^{1 \dagger}$, Daniel Sun $^{1 \dagger}$, Lauren Que ${ }^{2}$, Rebecca A Nebel ${ }^{3}$, Dylan Baker ${ }^{4}$, Patrick Popiel ${ }^{5}$, \\ Cindy L Amundsen ${ }^{6}$, Toby Chai ${ }^{5,7}$, Clare Close ${ }^{8}$, Michael DiSanto ${ }^{9}$, Matthew O Fraser ${ }^{10}$, Stephanie J Kielb ${ }^{11}$, \\ George Kuchel $^{4}$, Elizabeth R Mueller ${ }^{12,13}$, Mary H Palmer ${ }^{14}$, Candace Parker-Autry ${ }^{15,16}$, Alan J Wolfe ${ }^{17}$ \\ and Margot S Damaser ${ }^{1,18,19^{*}}$
}

\begin{abstract}
Females and males differ significantly in gross anatomy and physiology of the lower urinary tract, and these differences are commonly discussed in the medical and scientific literature. However, less attention is dedicated to investigating the varied development, function, and biology between females and males on a cellular level. Recognizing that cell biology is not uniform, especially in the lower urinary tract of females and males, is crucial for providing context and relevance for diverse fields of biomedical investigation. This review serves to characterize the current understanding of biological sex differences between female and male lower urinary tracts, while identifying areas for future research. First, the differences in overall cell populations are discussed in the detrusor smooth muscle, urothelium, and trigone. Second, the urethra is discussed, including anatomic discussions of the female and male urethra followed by discussions of cellular differences in the urothelial and muscular layers. The pelvic floor is then reviewed, followed by an examination of the sex differences in hormonal regulation, the urinary tract microbiome, and the reticuloendothelial system. Understanding the complex and dynamic development, anatomy, and physiology of the lower urinary tract should be contextualized by the sex differences described in this review.
\end{abstract}

Keywords: Sex differences, Lower urinary tract, Cell biology, Urology

\section{Background}

Sex refers to the biological classification of living things, generally as female or male, whereas gender is an individual's self-representation shaped by social and cultural associations with biological sex [1]. Both sex and gender can impact diagnosis and treatment in all areas of health and disease and, as a result, all areas of research should account for sex and gender in study design, analysis, interpretation, and data reporting. The ability to reproduce experimental data and the generalizability of results depend on such efforts [2].

Sex differentiation plays a key role in lower urinary tract (LUT) development and function. The foci of current research on LUT sex differences are anatomical and

\footnotetext{
* Correspondence: damasem@ccf.org

${ }^{\dagger}$ Benjamin Abelson and Daniel Sun contributed equally to this work.

${ }^{1}$ Glickman Urological and Kidney Institute, Cleveland Clinic Foundation, Cleveland, OH, USA

${ }^{18}$ Department of Biomedical Engineering, Lerner Research Institute, The Cleveland Clinic, 9500 Euclid Avenue, ND20, Cleveland, OH 44195, USA Full list of author information is available at the end of the article
}

physiological differences, while little attention has been paid to sex differences at the cellular level of the LUT. Further investigation of sex differences in LUT cell types is needed to better develop our understanding of normal and abnormal LUT function [3]. Elucidation of these differences in the LUT is essential to providing optimal treatment for urinary dysfunction in both women and men.

This review will cover the current research on sex differences in the LUT, highlighting areas in need of more research. With new NIH policies in place regarding sex as a biological variable [4], the review may serve as guide on the current status of sex differences in the LUT at the cellular level and indicate where future research efforts are needed.

\section{Cell populations in or associated with the LUT Detrusor smooth muscle}

The bladder provides a continent, neurologically controlled, compliant reservoir for urinary storage and a method to consciously void when appropriate. Voiding 
is controlled by the detrusor, which is the smooth muscle (SM) in the wall of the bladder from the insertion of the ureters to the dome (top) of the bladder. Three layers of SM comprise the detrusor. Longitudinal cells populate the inner and outer layers, whereas those cells found in the middle are arranged in a circular manner [5]. In humans, SM cells of varying sizes can form bundles that are connected by collagen fibers [6]. The bundles have the potential to function as a unit, or fascicle [5]. The interactions occurring amongst the SM cells dictate the behavior of the bladder wall.

The detrusor is thicker in men than women, as greater voiding pressure is needed to empty the bladder through the longer urethra of males [7]. The ratio between SM and connective tissue does not differ between women and men of any age [8]. Furthermore, it has been reported that contractility of human detrusor is sex-independent [9].

The human fetal bladder can be detected after the tenth week post-conception. Although it was classically thought that the bladder trigone is mesodermal in origin and the remainder of the bladder is derived from the endoderm, some studies have shown that trigone is also endodermal [10]. Favorito et al. evaluated the morphological differences in SM development between females and males [11], observing no differences in the volumetric densities of fetal nerve, SM cells, or collagen of either sex (13-20 weeks post-conception) [11]. No studies to date have reported morphological or physiological differences between female and male SM cells.

\section{Urothelium}

The urothelium is a specialized epithelium that lines the lumen and is five to seven cells thick, divided into three layers: an apical layer (comprised of umbrella cells only, one cell layer thick that is in contact with urine), an intermediate layer (comprised of intermediate cells, two to three cells thick), and a basal layer (comprised of basal cells two to three cells thick). The mucosa of the bladder is comprised of the urothelium and the underlying lamina propria [9]. Umbrella cells serve as a barrier between the urine and the underlying tissue. When the bladder is filled, the umbrella cells are stretched and flattened; whereas when the bladder is empty, the cells are cuboidal [12]. Seventy to $90 \%$ of the luminal facing membrane of the umbrella cells are covered by plaques giving the cells a "scalloped" appearance $[9,13]$. Plaques are made from uroplakins (UPs) that form hexagonal-shaped macromolecular structures providing additional barrier function besides tight junction proteins between the umbrella cells [13].

To date, four UPs have been found: UPIa $(27 \mathrm{kD})$, UPIb (28 kD), UPII (15 kD), and UPIII (47 kD) [14-16]. $\mathrm{Hu}$ et al. found defective glycosylation of UPs, smaller urothelial plaques, increased water permeability, vesicoureteral leakage, and enlarged ureteral orifices when
UPIIa was deleted in both female and male mice [17, 18]. Aboushwareb et al. found sex-specific effects for UPIIa and UPIII knockout (KO) mice. For example, male UPII KO mice experienced bladder decompensation, including elevated pressure changes and increased residual volume; in contrast, female UPII KO mice emptied their bladders normally [19]. The same group studied the excitability of detrusor myocytes in UP KO mice and discovered that female mice demonstrated decreased excitability, but male mice experienced no change [19]. These data support the fact that uroplakin deficiency results in urothelial defects that can lead to sex-specific bladder dysfunction.

The urothelium serves an additional function besides barrier function. Because of numerous ion channels and receptor proteins such as epidermal growth factor receptors (EGFR), adenosine, adrenergic, bradykinin, neurokinin, muscarinic, and purinergic receptors [20], the urothelial cells can serve to either transduce signals to surrounding cells (other urothelial cells or lamina propria cells) or respond to signals from surrounding cells. Thus, the urothelial cells can have a dual role of "sensor-transducer" function [21].

Animal studies in both sexes have been conducted to determine the sensitivity of the urothelium to changes in $\mathrm{pH}$. A family of acid-sensing ion channels (ASIC), $\mathrm{H}^{+}$-gated ion channels, are thought to help maintain $\mathrm{pH}$ within the urothelium of a mouse model [22]. ASIC1 is expressed in higher quantities in male mice, whereas ASIC2 is more abundant in females. The functional result of this difference in expression is unknown, although disruption of ASIC1 expression in the gut leads to a decrease in mechanical sensitivity [23]. The urothelium releases many small molecules and neurotransmitters in response to both mechanical and chemical stimuli [20]. Thus, ASIC may play a role in controlling bladder sensitivity to $\mathrm{pH}$ changes in the bladder.

Because the bladder urothelium plays an important role in the host innate immune response to UTI, and the fact that women are more prone to getting UTIs, the role of estrogen's effect on the urothelial defense mechanisms has been examined. These studies have been performed in female mice or urothelial tissues from female human subjects. Estrogen was found to mediate urothelial defense mechanisms against uropathogenic Escherichia coli (UPEC) in mice [24, 25], and estrogen's effect was through the ER $\beta$ and not the ER $\alpha$ receptor [24]. The translational relevance of these findings is that ER $\beta$, and not $E R \alpha$, is the estrogen receptor found in the bladder urothelium from female human subjects [26], and therefore, urothelial ER $\beta$ may play a more important role than ER $\alpha$ in UTI pathogenesis in women. A recent publication detected the presence of calcium-activated, voltage-gated, large conductance potassium channel (BK 
channel) on the umbrella urothelial cells [27]. Furthermore, urothelial BK channels were opened (activated) by lipopolysaccharides (LPS) suggesting that BK may work the same way in the urothelial cell as in macrophages where BK was important in regulating cytokine release when macrophages were exposed to LPS [28]. The possible link between $B K$ and ER $\beta$ in urothelial innate immune response is suggested by the finding that estradiol increased expression of BK channels via ER $\beta$ [29]. Loss of estrogen (by ovariectomies) in mice resulted in loss of protection against increased voiding frequency induced by intravesical LPS [30]. Estrogen's effects on the urothelium that protected against LPS' effects involved urothelial genes involved in inflammation and cellular metabolism [30]. These publications highlight estrogen's effects on bladder urothelium in urothelial defense mechanisms against UTI.

\section{Trigone}

The mechanistic basis of urinary continence involves relaxation of the detrusor and simultaneous contraction of the bladder neck. The trigone, a triangular-shaped complex of muscles, is demarcated by the bladder neck distally and the two ureters proximally [7]. The trigone is the least mobile aspect of the bladder as it is fused with the underlying detrusor that comprises the rest of the bladder [31]. In males, the bladder neck is contiguous with the prostatic urethra [7]. In females, both the bladder neck and urethra contact connective tissue of the anterior wall of the vagina; this positioning allows the bladder neck to be mobile but it is subject to stress, which can influence urinary continence [32]. A prime example is neuromuscular injury to the urethral sphincter during childbirth.

In males, the internal urethral sphincter is composed of SM that is arranged into long inner longitudinal and outer circular layers [33]. However, in women, the longitudinal cells do not form an internal sphincter. Oswald et al. found that although the growth of the bladder neck increased proportional to the gestational age, males (20-40-week gestation) have a denser internal sphincter and a significantly narrower bladder neck in comparison to females [34]. Similarly, Gilpin et al. showed that, in human fetuses, the circular SM around the bladder neck and proximal urethra was prominent in males but scant in females [35].This finding emphasizes the need for a sex-dependent study of the bladder neck during embryogenesis. Aside from looking at SM differentiation, more work is also needed to determine the exact populations of cells developing in the bladder neck.

\section{Urethra \\ Female urethra}

The adult female urethra is $3-4 \mathrm{~cm}$ in length [36, 37] (Fig. 1). It extends from the bladder neck to the external urethral orifice and is embedded behind the symphysis pubis [37]. Together, the bladder neck and proximal urethra form a functional rather than an anatomic internal sphincter. A cross section of the urethral wall reveals

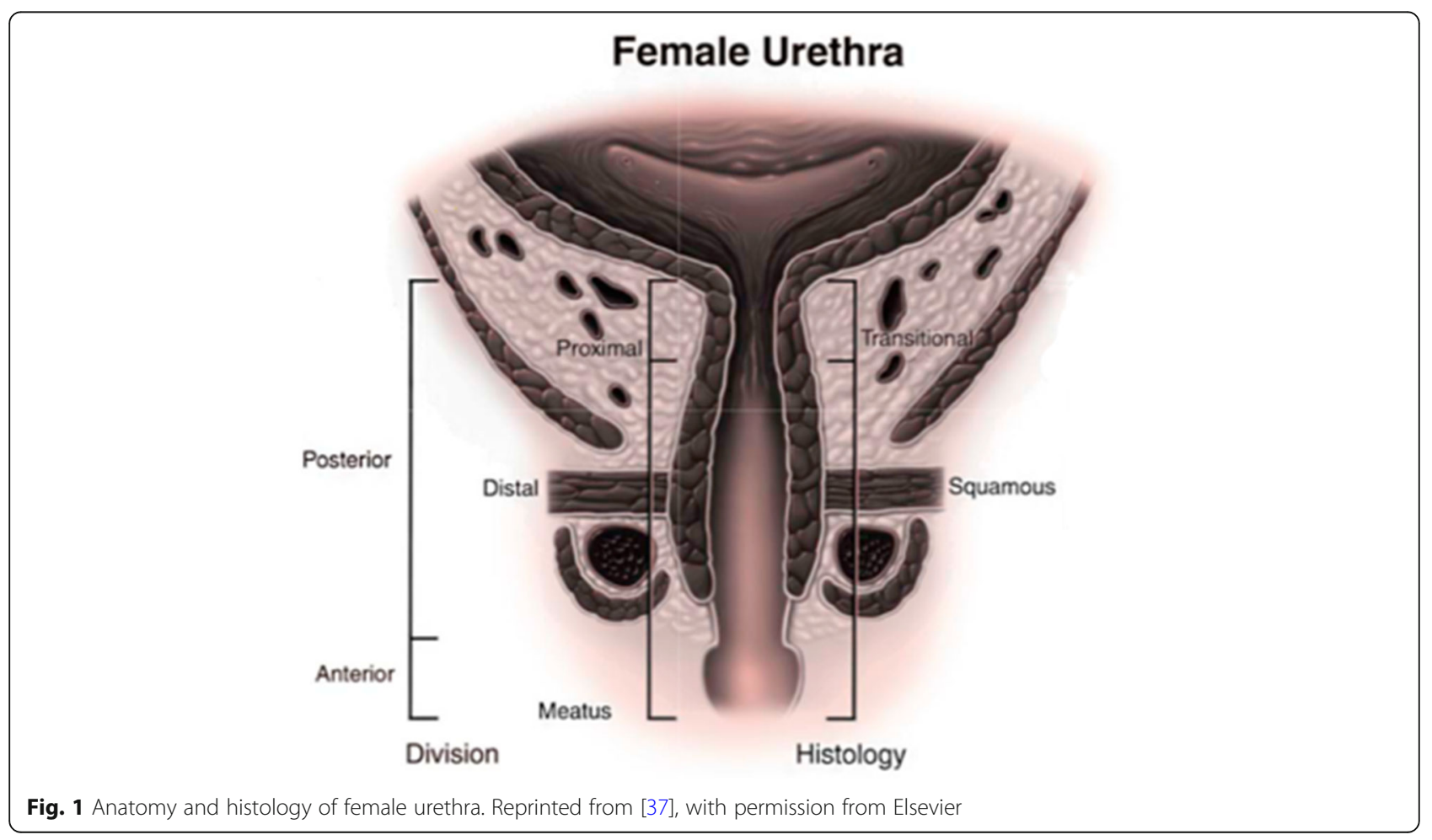


four tissue layers (from innermost to outer): (1) an inner epithelial lining, (2) a thick spongy sub-mucosa containing vascular supply, (3) a thin fascial layer, and (4) two layers of SM, an inner longitudinal layer and an outer circular layer [37, 38]. Although the proximal urethra in women is lined by transitional epithelial cells, this quickly transitions to squamous epithelial cells that line the majority of the female urethra [39].

The female urethra also can be divided into several unique sections based on paraurethral structures [6]. The first $20 \%$ of the urethra lines the bladder neck, whereas the following $20-60 \%$ of urethral length is surrounded by the striated urethral sphincter. The next segment of the urethra is surrounded by urogenital diaphragm, followed by the distal $20 \%$, which is surrounded by the bulbocavernosus muscle [40].
The distal sphincter, or rhabdosphincter, makes up the external urethral sphincter (EUS). The EUS, which is comprised of striated muscle in longitudinal and transverse configurations, is circular and incompletely surrounds the urethra. In females, the striated muscle located nearest to the vagina is significantly thinner, giving the rhabdosphincter a distinct horseshoe shape. Fibers from the trigonal plate bridge this incomplete ring [41]. Striated muscle in the distal urethral sphincter is circularly arranged and comprises the two bands that cover the ventral side of the urethra.

\section{Male urethra}

The male urethra has a diameter of $8-9 \mathrm{~mm}$, is approximately $18-20 \mathrm{~cm}$ long, and is divided into the anterior and posterior urethra [37] (Fig. 2). The anterior urethra

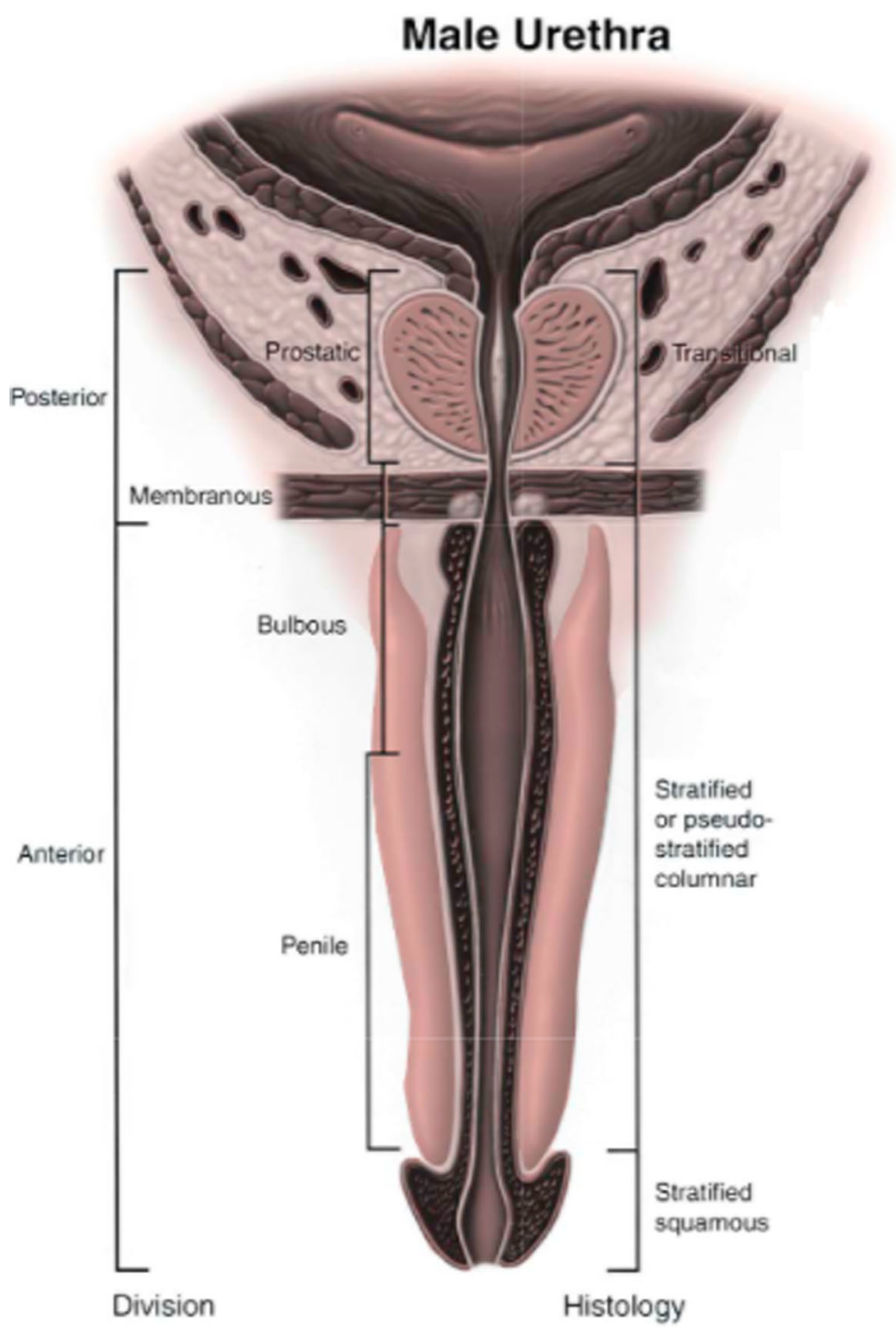

Fig. 2 Anatomy and histology of male urethra. Reprinted from [37], with permission from Elsevier 
extends from the perineal membrane to the urethral meatus and is divided into the penile urethra (surrounded by the corpus spongiosum) and the fossa navicularis (surrounded by the glans penis). The posterior urethra begins at the bladder neck, extending distally to the perineal membrane, and is subdivided into the prostatic urethra (bladder neck to prostatic apex) and the membranous urethra (from prostatic apex to perineal membrane).

The prostatic urethra is anteriorly displaced within the prostate and thus leaves the gland slightly anterior to the apex [42]. The urethral crest is a subtle ridge on the posterior aspect of the prostatic urethra that culminates in the verumontanum, an elevation in the posterior urethra that provides a crucial cystoscopic landmark for the male EUS. The male urethra angles about $30-35^{\circ}$ anteriorly distal to the verumontanum.

The membranous urethra is a $2-2.5-\mathrm{cm}$ stretch of urethra that passes through the perineal membrane and marks the site of the external sphincter, unique to the male urethra. Urothelium in the membranous urethra is surrounded by a layer of fibroelastic connective tissue (lamina propria) that separates it from the muscular layer, comprised of a thin SM layer and circularly oriented striated muscle fibers. This network of urethral muscle and connective tissue in addition to the pelvic floor muscles (described below) makes up the male EUS.

The bulbar urethra begins distal to the perineal membrane, which lies just anterior to the inferior margin of the pubic symphysis. After about $2 \mathrm{~cm}$, the penile urethra begins which continues until it dilates into the fossa navicularis which is surrounded by the glans penis, until it terminates at the urethral meatus, the narrowest part of the urethra [43].

\section{Urethral smooth muscle}

The SM layer of the urethra contains oblique and longitudinal muscle fibers surrounded by circular fibers in both women and men [43]. These muscles are supported by pelvic floor muscles, described elsewhere in this review. Throughout the course of the urethra, the SM cell layer provides a baseline resistance to urine flow, which is reinforced by the rich vascularity of the urethra.

Both $\alpha 1$ - and $\alpha 2$-adrenoceptors contribute to urethral SM contractility, relaxing during voiding and contracting during filling. Binding receptor assays reveal that male rabbits have equivalent amounts of $\alpha 1$ - and $\alpha 2$-adrenoceptors, whereas the females have a significantly denser population of $\alpha 2$-adrenoceptors [44] (Table 1). To expand upon this finding, Alexandre et al. observed the effects of different agonists and antagonists on urethral SM in both mice and marmosets. Phenylephrine, norepinephrine, $\mathrm{KCl}$, and electrical-field stimulation induced larger contractions in the male mice and marmosets [45]. However, there was no sex difference observed in response to $\mathrm{N}$-nitro-L-arginine, atropine, or a P2X1-purinoceptor antagonist. Urethral mRNA expressions of $\alpha 1_{\mathrm{A}}$-adrenoceptor (a subtype of $\alpha 1$-adrenoceptors) and tyrosine hydroxylase were significantly higher for males than females [45]. It is a possibility therefore that $\alpha 1$-adrenoceptors are not as important for contraction and functionality in female rabbits.

Few studies have specifically examined the differences in the development of female and male urethral SM. Oswald et al. studied fetal development of the internal urethral sphincter in 37 human fetuses. They found that the internal sphincter muscle of male fetuses had a significantly larger volume compared to female fetuses, in part due to hypertrophy of the SM at this level, leading to smaller lumens. They postulated that this could be resultant from hypertrophy induced by transient urethral obstruction distal to the bladder neck and hormone influenced (testosterone) dependent growth [34]. Important in both male and female fetuses, Jin et al. found that SM differentiation in the bladder and urethra is crucial for the Wolffian duct orifice descent [46].

\section{Urethral striated muscle}

Striated muscle in the LUT is essential for providing support to the pelvic floor and coordinating the initiation of micturition, the emptying of urine from the bladder. The architecture of striated muscle in these two locations is similar: an arrangement of muscle fibers and

Table 1 Urethral smooth muscle sex differences summary

\begin{tabular}{|c|c|c|c|c|}
\hline Species & Sex & Histologic studies & Functional studies & References \\
\hline \multirow[t]{2}{*}{ Rabbit } & Female & $\begin{array}{l}\text { Greater density of a2 adrenoreceptor compared } \\
\text { to a1 (122 vs. } 33 \mathrm{fmol} / \mathrm{mg} \text { ) }\end{array}$ & Large contractile response to a2 agonist & Morita et al. [44] \\
\hline & Male & $\begin{array}{l}\text { Equal amounts of a } 2 \text { and a } 1 \text { adrenoreceptors } \\
\text { ( } 32 \text { vs. } 34 \mathrm{fmol} / \mathrm{mg} \text { ) }\end{array}$ & Small contractile response to a 2 agonist & \\
\hline \multirow[t]{2}{*}{ Mouse } & Female & Scant a1-adrenoreceptor expression & Smaller contractions in response to agonist & Alexandre et al. [45] \\
\hline & Male & Abundant a1-adrenoreceptor expression & Large contractions in response to agonist & \\
\hline \multirow[t]{2}{*}{ Human } & Female & $\begin{array}{l}\text { During development, urethral SM had smaller volumes }\left(4.95 \mathrm{~mm}^{3}\right) \\
\text { and wider lumens }\left(1.2 \mathrm{~mm}^{2}\right)\end{array}$ & & Oswald et al. [34] \\
\hline & Male & $\begin{array}{l}\text { During development, urethral SM had larger volumes }\left(12.04 \mathrm{~mm}^{3}\right) \\
\text { and narrower lumens }\left(1.18 \mathrm{~mm}^{2}\right)\end{array}$ & & \\
\hline
\end{tabular}


connective tissue (Table 2). From a macro-, micro-, to nano-scale, striated muscle is organized by whole muscle, muscle bundles, and muscle fibrils and myofibrils interlaced by connective tissue: epimysium, perimysium, and endomysium, respectively $[47,48]$. There are two classifications for striated muscle fibers: slow twitch (type I) and fast twitch (type II). Type I fibers have more acid-stable ATPase, abundant mitochondria, thicker Z-disks, high amounts of strong oxidative enzymes, and a twitch tension of $\sim 100 \mathrm{~ms}$. Type II fibers have a higher concentration of alkaline-stable ATPases, fewer mitochondria, and a twitch tension of $\sim 30 \mathrm{~ms}[49,50]$. Fiber type composition of striated muscle influences susceptibility to damage and repair and varies with sex as described below.

A comprehensive study of the striated sphincter muscle has been investigated in rats. Female and male urethras differ macro- and microscopically. Unlike typical skeletal muscles, female sphincter myofibrils are three to five times smaller in diameter than striated muscle from the pelvic floor [51]. This thinness corresponds to a lack of peripheral localization of nuclei. Instead, the nuclei are centrally localized and are of similar size to the diameter of the fibril. Additionally, unlike other skeletal muscles, these cells lack anchorage points and are in direct contact with neighboring connective tissue [51, 52]. In male rats, two longitudinal strips of connective tissue segment the sphincter into two lateral bundles; the myofibrils do not form myotendinous junctions with neighboring connective tissue [53]. Striated muscle forms a thick layer, observable by the eye, in male rats whereas in females, it is thin and circular [51].

Similar to skeletal muscle, desmin and dystrophin are expressed by rat striated urethral muscle; thus, both proteins are used for cell characterization. Desmin runs orthogonal to the Z-lines, outlining the sarcomeres, whereas dystrophin is localized in female rat sarcolemma [51]. Dystrophin is expressed in striated muscle but not urethral SM and is thus a good marker for differentiating between the two types of muscle [54]. Additionally, expression of slow and fast myosin heavy chains can be used to investigate striated muscle type using specific monoclonal antibodies. With the exception of the bladder neck, striated muscles prominently occupy the mid-region of the urethra [52]. Initially, it was thought that female rats contained a mixture of fast and slow fibers [55]. However, recent studies using immunohistochemistry have revealed that fast twitch fibers are predominant $[51,52,56]$. In male rats, Chen et al. observed 100\% type II fast twitch fibers in the upper regions of the urethra [57]. Bierinx et al. found two types of myofibrils in male rats. All myofibrils expressed type II fast MHC similar to the female rat; however, in selected fibers taken near the urethral lumen, they co-expressed slow MHC [53]. In the female urethra, a thick layer of SM separates the lumen from the striated muscle. In males, SM is only observed near ducts (i.e., seminal, prostatic) and in the urethral lumen. Thus, Bierinx et al. hypothesize that the presence of these co-expressing fibrils in the male urethral lumen may play a role in continence similar to the SM in females [58].

Streng et al. used transvesical cystometry and ultrasound transducers to determine bladder pressure and flow rate changes in striated muscle taken from the distal regions of male and female urethras [59]. No sex difference was observed in bladder pressure oscillations and in discontinuous flow rates. However, a difference was observed in voiding mechanism. In females, the flow rate and bladder pressure are closely related; if the pressure increases, the flow begins and if the pressure decreases, the flow ceases. Although the flow is constant, it is interrupted for short periods of time when the bladder pressure increases and the urethral sphincter partially or fully closes. Streng et al. hypothesizes that this relationship is due to slow twitch fibers in females transiently closing the urethra and leading to pressure increments and flow stoppage [59]. Overall, female rats experience shorter micturition times and their maximal flow rate is

Table 2 Urethral striated muscle sex differences summary

\begin{tabular}{lllll}
\hline Species & Sex & Histologic studies & Functional studies & References \\
\hline Rat & Female & Striated muscle is thin and circular, & Urine flow disrupted by & Praud et al. [51] \\
& & prominently occupying the middle urethra. & partial/full closure of urethra & Lim et al. [52] \\
& Type II fibers are predominant. & Lower max flow rate & Buffini et al. [56] \\
& & and shorter micturition time & Biérinx et al. [53] \\
& & & Streng et al. [59]
\end{tabular}

$\begin{array}{ll}\text { Male } & \begin{array}{l}\text { Striated muscle forms a thick layer. } \\ \text { 100\% type II fibers in the upper urethra. } \\ \text { Luminal muscle contains a mix of type I and II fibers. }\end{array} \\ \text { Human } \quad \text { Female } \quad \begin{array}{l}\text { Striated muscle extends the length of the urethra } \\ \text { and is composed of predominantly type I slow twitch fibers } \\ (87 \% \text { vs. 13\%). }\end{array} \\ \text { Male } \quad \begin{array}{l}\text { Striated muscle extends from the membranous urethra } \\ \text { over the prostate and has a mixture of both slow and fast twitch fibers } \\ (65 \% \text { vs. 35\%). }\end{array}\end{array}$


lower. In males, there is a spike in flow before maximal bladder pressure is reached, followed by a slow decline in flow rate.

In addition to the extensive work in rats regarding the urethral striated muscle, human studies have also revealed key differences between males and females. In 1981, Gosling et al. observed a single population of type I (slow twitch) fibers, $15-20 \mu \mathrm{m}$ in diameter, in both female and male EUS using histochemistry and electron microscopic analysis of samples obtained through cystourethrectomy [50]. They also observed a mixture of slow and fast fibers in the periurethral levator ani. Further studies conducted by Brading et al., Benoit et al., and $\mathrm{Ho}$ et al. revealed that in females, the striated muscle extends the length of the urethra and is composed of predominantly type I slow twitch fibers [6062]. In males, striated muscle extends from the membranous urethra over the prostate and has a mixture of both slow and fast twitch fibers [63, 64]. Ho et al. observed two types of slow twitch fibers: one of smaller diameter $(15.7 \mu \mathrm{m})$ and the other of larger diameter $(21.7 \mu \mathrm{m})$. Aside from size, the difference between these two types of slow twitch fibers is unknown.

Identification of nitrergic nerve fibers within human rhadosphincter suggests that nitric oxide may play a role in striated muscle control in the urethra [63, 65]. Nitric oxide synthase (NOS) produces nitric oxide which mediates urethral SM relaxation in various animals [66-68]. Eighty-six percent of fast twitch and $29 \%$ of slow twitch fibers exhibited NOS immunoreactivity in the sarcolemma of the male EUS [63]. Since females have predominantly slow twitch fibers, further studies are needed to determine if there is a mixed slow twitch fiber population as seen in males. Additionally, the percentage of NOS immunoreactivity should be determined for women.

\section{Pelvic floor striated muscle}

The pelvic floor, or pelvic diaphragm, is a bowl-shaped structure that is composed of complex interconnected ligaments and striated muscles. This musculature provides support/resistance to abdominal pressure, supports abdominopelvic viscera, and aids in fecal and urinary continence [69]. The muscular components of the pelvic floor include the levator ani muscles and the coccygeus muscle $[69,70]$. The levator ani is composed of three types of intermediate muscle fibers: the puborectalis, pubococcygeus, and iliococcygeus. These muscles are attached to the pelvis: anteriorly, behind the pubic bodies of the hip; laterally, fascia of the obturator internus muscle; posteriorly, coccyx. Gaps within the musculature, the urogenital hiatus and the rectal hiatus, allow for urination and defecation.

The puborectalis is U-shaped; originating at the pubic bone, it slings around and bends at the anorectal junction forming the anorectal angle $\left(90^{\circ}\right)$. Relaxing and contracting of the puborectalis maintains fecal continence [71]. The pubococcygeus fibers constitute the main muscle body in the levator ani. They initiate symmetrically at the pubis, run along the obturator internus, and attach together at the coccyx. Some fibers also loop around to surround the prostate in men (levator prostate) and the vagina in women (pubovaginalis). Within the pubococcygeal muscle is the anococcygeal ligament, which is a midline graft that extends from the anal cavity to the coccyx. Finally, the iliococcygeus muscle attaches at the coccyx and the posterior of the obturator internus, or the tendinous arch [42]. All three muscles of the levator ani attach laterally to the obturanus internal fascia where there is a thickening of fibers.

The levator ani muscles contain a heterogeneous population of type I and type II fibers, but histological analyses have shown that the type I, or slow twitch, fibers predominate [50] (Table 3). This correlates clinically with the static nature of the pelvic floor and its role in supporting the abdominal viscera. The smaller population of type II, fast twitch, fibers are likely recruited for assistance during periods of increased abdominal pressure (i.e., coughing, sneezing) [50]. The number and diameter of these fibers decrease with age [72]. There are no reported differences between females and males in the proportions of these fibers. A group of German investigators analyzed the pelvic floor muscles of young, healthy, female and male cadavers. Due to small sample size, no quantitative analyses were performed, but they reported no histomorphological differences between female and male specimens [73].

In 1991, Tobin et al. showed that the levator ani muscle of the developing rat fetus exhibits sexual dimorphism [74]. Levator ani (LA) muscles were removed from

Table 3 Pelvic floor striated muscle sex difference summary

\begin{tabular}{lll}
\hline Species & Sex & Histologic studies \\
\hline Rat & Female & $\begin{array}{l}\left.\text { Developing LA muscle contains fewer motor units with smaller cross-sectional areas (89.2 } \mu m^{2}\right) \\
\text { Fewer number of satellite cells in the neonatal LA muscle }\end{array}$ \\
& Male & $\begin{array}{l}\left.\text { Developing LA muscle contains more motor units with greater cross-sectional areas (120.8 } \mu m^{2}\right) \\
\text { Greater number of satellite cells in the neonatal LA muscle }\end{array}$ \\
Human & Female & Developing LA muscle is thin, and its bundles are integrated with connective tissue \\
& Male & Developing LA muscle constitutes a thick, muscular layer
\end{tabular}


22-day-old female and male embryos and subjected to morphological analysis. The investigators found that female LA muscles contained significantly fewer motor units (MU) (153 versus 350) and each unit had comparatively smaller cross-sectional areas $\left(89.2 \mu \mathrm{m}^{2}\right.$ versus $120.8 \mu^{2}$ ). As the rats developed postnatally, the cross-sectional area of the MU decreased for both sexes and were equivalent by postnatal day 3 (approximately $33 \mu \mathrm{m}^{2}$ ). Conversely, the number of motor units in males increased rapidly to 2726 by postnatal day 6 , while in females, the number of MUs only increased modestly to 355. The authors posit that exposure to testosterone is responsible for this differential LA muscle development [74]. Satellite cells, a population of myogenic stem cells residing at the periphery of muscle fibers, seem to be influenced by androgens and may play a role in this sexual dimorphism. Niel et al. found that the number of satellite cells in the neonatal rat LA muscle was increased in males compared to females [75]. With prenatal exposure to testosterone, the number of satellite cells in the female group increased as well as the size of the LA muscle. The authors conclude that the sex differences found in the developing rat LA are attributed to sexual dimorphism in satellite cells, which may be androgen-sensitive [75].

These animal studies are in concordance with another study that investigated sex differences in the levator ani muscle of human fetuses [76]. They show that at the same point in development, the male levator ani muscle constitutes a thick muscular layer, while in the female, the LA muscle is thin and its bundles are integrated with connective tissue [76]. Further studies are necessary to elucidate the developmental differences between female and male pelvic floor musculature in humans.

\section{Reticuloendothelial system (e.g., immune cells)}

Urinary tract infections (UTIs) affect nearly 160 million individuals each year [77], and nearly half of women experience recurrence of UTIs [78]. Such sex-related vulnerability has been commonly attributed to anatomical differences involving the female lower urinary tract. Observations in support of this view include the fact that the female external urethra is in close proximity to the entrance of the vagina, which houses large numbers of microbes [79]. The current view is that bacteria migrate from the gut to the vagina and then to urethra, evidenced by the prevalence of native bowel flora that become uropathogens [57].

The mucosal layer of the urothelium is consistently exposed to countless microbes. Micturition is a passive mechanism for removing threats of infection. However, using single-molecule atomic force microscopy, Miller et al. found that uropathogenic E. coli (UPEC) utilize the flow of urine to extend adhesive surface appendages called pili to attach and secure themselves to the host epithelium
[80]. The mucin layer provides a secondary defense, inhibiting bacterial attachment to the mucosal wall $[81,82]$.

While the mucosal layer is an important anatomical line of defense, more recent evidence supports the existence of nonstructural contributors rendering women more vulnerable to UTI. For the most part, this vulnerability is thought to stem from the reticuloendothelial system (RES), which provides the host immunity against microbes [83]. The RES includes antigen-presenting cells also known as $\mathrm{MHII}^{+}$, macrophages, dendritic cells, $\mathrm{CD}_{11 \mathrm{~b}^{+}}$and $\mathrm{CD}_{103}{ }^{+}$cells, and monocytes [83]. In addition, neutrophils and monocytes can enter the bladder upon UPEC infection [84, 85]. Mora-Bau et al. found that a majority of infiltrating monocytes differentiate into macrophages, which may then impair adaptive immune responses to UTI [83].

Mora-Bau et al. studied the role of prominent immune cells-CD $45^{+}$, macrophages, dendritic cells, and monocytes-in bacterial clearance in female mice bladders [83]. Depletion of monocytes had little effect on bacterial clearance. Macrophages have been hypothesized to adapt an immune response via cytokine secretion or antigen sequestration. When depleting mice of macrophages, no change was observed for effecter cell infiltration or cytokine secretion; however, there was an increase in the number of dendritic cells containing UPEC cells [83]. In addition, absence of $\mathrm{B}$ and/or $\mathrm{T}$ cells severely impaired the defense of female bladders against UPEC [83]. Although there was an increase in immune response, it did not alter reinfection nor remove the bacteria. Also, mast cell-derived IL-10 enhanced immune tolerance and decreased response to infection in the bladder, enhancing the risk of chronic infection [86].

A study of cells in the mucosal layer biopsied from women found increased numbers of CD4+ and CD8+ cells for those with interstitial cystitis, suggesting these cells play a crucial role in the innate pathogenesis of the female bladder [87]. Interestingly, these increased numbers were found in the urothelium and not the detrusor. A thin layer of glycosaminoglycans populate the urothelium, and no difference was observed for either sex or by region of the rabbit bladder [88]. More research is needed to determine if the differences in rate of UTI between women and men is related to differences in the innate ability of the RES to fight infection.

\section{Microbiome}

Clinicians often equate the presence of bacteria in urine with infection. This concept is based on the long-held dogma that urine is sterile. Recently, however, researchers have used next-generation sequencing and enhanced culture methods to detect communities of bacteria, fungi, and viruses (microbiota) in catheterized urine collected directly from the female bladder [89-95]. 
Thus, the "sterile urine" paradigm is no longer valid. Other studies have revealed associations between bladder bacteria and post-operative and post-instrumentation UTIs [96, 97], urgency urinary incontinence [98, 99], and response to overactive bladder treatment [100]. These findings suggest that the urinary tract possesses its own protective microbiota and that disruption (dysbiosis) of this community results in LUT symptoms (for recent reviews, see [101-103]).

The bacteria most commonly detected in the bladders of adult women are members of the genera Lactobacillus, Gardnerella, Streptococcus, and Staphylococcus [98-100]. Typical uropathogens (e.g., UPEC) are rarely detected, except in women experiencing UTI symptoms. Indeed, the conventional view that UTI is almost always caused by UPEC is suspect, as the standard urine culture protocol performed by clinical microbiology laboratories worldwide misses the vast majority of non-E. coli uropathogens most of the time [104]. These results argue against the conventional E. coli-centric view of UTI [105].

While almost all bladder microbiota research has been performed in peri-menopausal women, preliminary studies of pregnant women and men have been reported. Intriguingly, the bladder microbiota of women whose pregnancies went to full term resemble those of older peri-menopausal women [106]. Live bacteria have also been detected in urine obtained by a catheter from older men. The study sample size is too small to conclude much, except that the male urinary bladder is probably also not sterile [127]. Thus, the discovery of the bladder microbiota offers an exciting opportunity to advance our understanding of LUT health and disease.

\section{The role of hormones in sex differences in the LUT}

Receptors for estrogen, progesterone, and testosterone can be found in the LUT of both sexes across species and across developmental time periods [107-112]. This suggests an important role for reproductive hormones in LUT development and/or maintenance, although the expression and underlying regulatory mechanisms of sex hormone receptor expression can vary between sexes.

In female and male mice, SM cells and lamina propria fibroblasts of the urethral wall had a high density of estrogen receptor- $\alpha(E R \alpha)$, estrogen receptor- $\beta(E R \beta)$, and progesterone receptor (PR)-positive cells [112]. ER $\beta+$ and $\mathrm{PR}+$ cells have also been observed in the urethral epithelium, while ER $\beta+$ cells are found in the bladder epithelium and detrusor of both sexes. In females, only ER $\beta$ was detected in the bladder urothelium [26]; whereas in male bladder urothelium, no ER expression was detected [113]. The caveat here is that the female study was done in 2009 after the discovery of ER $\beta$ in 1996 [114], whereas the male study was done in 1995 prior to the discovery of ER $\beta$; thus, no antibody for ER $\beta$ was available. In males only, ER $\beta$ and PR are present in striated muscle cells of the rhabdosphincter. In females, PR co-localized mostly with ER $\alpha$. Knocking out ER $\alpha$ in the LUT of female mice resulted in reduced numbers of PR-positive cells in the urethra, suggesting that ER $\alpha$ mediates PR expression in the female urethra [112]. In contrast, disrupting expression of either ER $\alpha$ or ER $\beta$ in males did not change PR expression in the urethra.

Reproductive hormones have also been shown to play a role in LUT structure and integrity. Female rats that have undergone oophorectomy have a thinner bladder wall and widened spaces between detrusor fascicles compared to controls [115]. Injections with either estrogen or testosterone reversed these effects [115]. In males, following castration either before or after puberty, pelvic neurons are significantly smaller than those in noncastrated control male rats [109]. Testosterone replacement following surgery remediated these effects, signifying that testosterone is important for maturation and maintenance of autonomic pelvic neurons in males [109]. In contrast, estrogen replacement had no effect on male rat pelvic ganglia [116].

In female rabbits, injections of either progesterone or testosterone slightly reduce bladder capacity and compliance, while treatment with estrogen increases bladder capacity and compliance [108, 117]. In male rabbits, injections of either testosterone or estrogen significantly increases bladder capacity but progesterone treatment has no effect [118]. The cyclical nature of estrogen and progesterone is associated with worsening LUT symptoms prior to menstruation [119]. Furthermore, urethral length is increased midcycle of the menstrual cycle, at a time of high estrogen, compared to other phases [120]. Vaginal estrogen has been shown to reduce LUT symptoms associated with genitourinary syndrome of menopause, such as UTIs and overactive bladder [119].

$\mathrm{ER} \alpha, \mathrm{ER} \beta$, and the androgen receptor (AR) are also thought to play a role in bladder cancer development and progression [121-124]. Some studies show that the loss of AR or ER $\alpha$ expression is associated with higher grade/more pathologic tumors in the bladder [121, 123], while increased expression of $\operatorname{Er} \beta$ is associated with these same tumor types [123]. However, other studies show conflicting results [125].

It is clear that reproductive hormones have a role in LUT function and that these hormones can mediate different effects in females compared to males. What remains unknown is the mechanisms underlying the role of these hormones in the LUT of both sexes. Indirect effects of reproductive hormones, such as the role of estrogen in regulating adrenergic receptors in the LUT or its involvement in urothelial cell proliferation through different ER subtypes, have been demonstrated [126]. However, the presence of reproductive hormone 
receptors in both sexes suggests direct effects may also be possible [108].

\section{Conclusions}

Sex differences in LUT cells influence form and function. For example, variations in development of the rhabdosphincter result in the observed sexual dimorphism in voiding patterns, while differential expression of immune cells in the bladder mucosa or the differential responses of the urothelium may amplify the rate of urinary tract infections in women. Along with anatomical and functional variations between women and men, developmental and morphologic disparities on the cellular level need to be taken into account when treating pathology. Research in this field is still immature, and further investigation is needed to answer questions such as the following: How do sex differences in urinary microbiome impact susceptibility to urinary tract infections? How does the complex interplay between sex hormones and the lower urinary tract mediate development, physiology, and susceptibility to malignancy? Do sex differences in native reticuloendothelial system cell populations mediate variations in susceptibility to urinary tract infections? Can improved understanding of the complex development of male and female LUT stimulate breakthroughs in the diagnosis and management of LUT dysfunction? This review should serve as a guideline to current knowledge regarding LUT sex differences, as well as a catalyst for investigators wishing to contribute to the field.

\section{Abbreviations}

AR: Androgen receptor; ASIC: Acid-sensing ion channels; EGFR: Epidermal growth factor receptors; ERa: Estrogen receptor-a; Er $\beta$ : Estrogen receptor- $\beta$; KO: Knockout; LA: Levator ani; LPS: Lipopolysaccharides; LUT: Lower urinary tract; MU: Motor units; NOS: Oxide synthase; PR: Progesterone receptor; RES: Reticuloendothelial system; SM: Smooth muscle; UPEC: Uropathogenic E. coli; UTI: Urinary tract infection

\section{Funding}

This work was supported by programmatic grants from Astellas Pharma US, Inc., the Allergan Foundation, Cook Medical, and Kimberly-Clark Corp.

\section{Authors' contributions}

$B A, D S, L Q, R A N$, and $M D$ were major contributors in conceiving and writing the manuscript. All other authors contributed to the writing of the manuscript. All authors read and approved the final manuscript.

\section{Ethics approval and consent to participate}

Not applicable

\section{Consent for publication}

Not applicable

\section{Competing interests}

Dr. Wolfe has received research funding from Astellas Scientific Medical Affairs and Kimberly Clark Corporation. All other authors declare that they have no competing interests.

\section{Publisher's Note}

Springer Nature remains neutral with regard to jurisdictional claims in published maps and institutional affiliations.

\section{Author details}

Glickman Urological and Kidney Institute, Cleveland Clinic Foundation, Cleveland, OH, USA. ${ }^{2}$ Department of Biophysics and Biophysical Chemistry, Johns Hopkins School of Medicine, Baltimore, MD, USA. ${ }^{3}$ Society for Women's Health Research, Washington, DC, USA. ${ }^{4}$ UConn Center on Aging, University of Connecticut, 263 Farmington, Farmington, CT, USA.

${ }^{5}$ Department of Obstetrics, Gynecology \& Reproductive Sciences, Yale School of Medicine, New Haven, CT, USA. ${ }^{6}$ Department of Obstetrics and Gynecology, Division of Urogynecology and Reconstructive Surgery, Duke University, Durham, NC, USA. ${ }^{7}$ Department of Urology, Yale School of Medicine, New Haven, CT, USA. ${ }^{8} \mathrm{Cl}$ ose Pediatric Urology, Henderson, NV, USA. ${ }^{9}$ Department of Biomedical Sciences, Cooper Medical School of Rowan University, Camden, NJ, USA. ${ }^{10}$ Department of Surgery, Division of Urology, Duke University Medical Center, Durham, NC, USA. ${ }^{11}$ Department of Urology and Obstetrics and Gynecology, Northwestern University Feinberg School of Medicine, Chicago, IL, USA. ${ }^{12}$ Department of Urology, Loyola University Chicago, Maywood, IL, USA. ${ }^{13}$ Department of Obstetrics/Gynecology, Loyola University Chicago, Maywood, IL, USA. ${ }^{14}$ School of Nursing, University of North Carolina at Chapel Hill, Chapel Hill, NC, USA. ${ }^{15}$ Department of Obstetrics and Gynecology, Wake Forest School of Medicine, Winston-Salem, NC, USA. ${ }^{16}$ Department of Urology, Wake Forest School of Medicine, Winston-Salem, NC, USA. ${ }^{17}$ Department of Microbiology and Immunology, Loyola University Chicago, Health Sciences Division, Stritch School of Medicine, Maywood, IL 60153, USA. ${ }^{18}$ Department of Biomedical Engineering, Lerner Research Institute, The Cleveland Clinic, 9500 Euclid Avenue, ND20, Cleveland, OH 44195, USA. ${ }^{19}$ Louis Stokes Cleveland VA Medical Center, Cleveland, OH, USA.

Received: 20 June 2018 Accepted: 26 September 2018

Published online: 22 October 2018

\section{References}

1. Institute of Medicine. Exploring the biological contributions to human health: does sex matter? Washington, DC: The National Academies Press; 2001.

2. Collins FS, Tabak LA. Policy: NIH plans to enhance reproducibility. Nature. 2014;505:612-3.

3. Losada L, Amundsen CL, Ashton-Miller J, Chai T, Close C, Damaser M, DiSanto M, Dmochowski R, Fraser MO, Kielb SJ, et al. Expert panel recommendations on lower urinary tract health of women across their life span. J Women's Health (Larchmt). 2016;25:1086-96.

4. Clayton JA, Collins FS. Policy: NIH to balance sex in cell and animal studies. Nature. 2014;509:282-3.

5. Andersson KE, Arner A. Urinary bladder contraction and relaxation: physiology and pathophysiology. Physiol Rev. 2004;84:935-86.

6. DeLancey J, Gosling J, Creed K, Dixon J, Delmas V, Landon D, Norton P. Gross anatomy and cell biology of the lower urinary tract. In: Abrams $P$, Cardozo L, Khoury S, Wein A, editors. Second international consultation on incontinence. Plymouth: Health Publication; 2002. p. 17-82

7. Mangera A, Osman NI, Chapple CR. Anatomy of the lower urinary tract. Surg Oxf Int Ed. 2013;31:319-25.

8. Lepor H, Machi G. Comparison of AUA symptom index in unselected males and females between fifty-five and seventy-nine years of age. Urology. 1993:42:36-40.

9. Fry $\mathrm{CH}$, Bayliss $\mathrm{M}$, Young JS, Hussain M. Influence of age and bladder dysfunction on the contractile properties of isolated human detrusor smooth muscle. BJU Int. 2011;108:E91-6.

10. Tanaka ST, Ishii K, Demarco RT, JCt P, Brock JW 3rd, Hayward SW. Endodermal origin of bladder trigone inferred from mesenchymal-epithelial interaction. J Urol. 2010:183:386-91.

11. Favorito LA, Pazos HM, Costa SF, Costa WS, Sampaio FJ. Morphology of the fetal bladder during the second trimester: comparing genders. J Pediatr Urol. 2014;10:1014-9.

12. Khandelwal P, Abraham SN, Apodaca G. Cell biology and physiology of the uroepithelium. Am J Physiol Ren Physiol. 2009;297:F1477-501.

13. Walz T, Haner M, Wu XR, Henn C, Engel A, Sun TT, Aebi U. Towards the molecular architecture of the asymmetric unit membrane of the mammalian urinary bladder epithelium: a closed "twisted ribbon" structure. J Mol Biol. 1995;248:887-900.

14. Lin JH, Wu XR, Kreibich G, Sun TT. Precursor sequence, processing, and urothelium-specific expression of a major 15-kDa protein subunit of asymmetric unit membrane. J Biol Chem. 1994;269:1775-84. 
15. Wu XR, Sun TT. Molecular cloning of a $47 \mathrm{kDa}$ tissue-specific and differentiationdependent urothelial cell surface glycoprotein. J Cell Sci. 1993;106(Pt 1):31-43.

16. Yu J, Lin JH, Wu XR, Sun $T$. Uroplakins la and Ib, two major differentiation products of bladder epithelium, belong to a family of four transmembrane domain (4TM) proteins. J Cell Biol. 1994;125:171-82.

17. Hu P, Deng FM, Liang FX, Hu CM, Auerbach AB, Shapiro E, Wu XR, Kachar B, Sun $\Pi$. Ablation of uroplakin III gene results in small urothelial plaques, urothelial leakage, and vesicoureteral reflux. J Cell Biol. 2000;151:961-72.

18. Hu P, Meyers S, Liang FX, Deng FM, Kachar B, Zeidel ML, Sun TT. Role of membrane proteins in permeability barrier function: uroplakin ablation elevates urothelial permeability. Am J Physiol Ren Physiol. 2002;283:F1200-7.

19. Aboushwareb T, Zhou G, Deng FM, Turner C, Andersson KE, Tar M, Zhao W, Melman A, D'Agostino R Jr, Sun TT, Christ GJ. Alterations in bladder function associated with urothelial defects in uroplakin II and IIla knockout mice. Neurourol Urodyn. 2009;28:1028-33.

20. Apodaca G, Balestreire E, Birder LA. The uroepithelial-associated sensory web. Kidney Int. 2007;72:1057-64.

21. Birder LA. Urothelial signaling. Handb Exp Pharmacol. 2011;202:207-31.

22. Kobayashi H, Yoshiyama M, Zakoji H, Takeda M, Araki I. Sex differences in the expression profile of acid-sensing ion channels in the mouse urinary bladder: a possible involvement in irritative bladder symptoms. BJU Int. 2009;104:1746-51.

23. Page AJ, Brierley SM, Martin CM, Price MP, Symonds E, Butler R, Wemmie JA, Blackshaw LA. Different contributions of ASIC channels 1a, 2, and 3 in gastrointestinal mechanosensory function. Gut. 2005;54:1408-15.

24. Luthje P, Brauner H, Ramos NL, Ovregaard A, Glaser R, Hirschberg AL, Aspenstrom P, Brauner A. Estrogen supports urothelial defense mechanisms. Sci Transl Med. 2013;5:190ra180.

25. Wang C, Symington JW, Ma E, Cao B, Mysorekar IU. Estrogenic modulation of uropathogenic Escherichia coli infection pathogenesis in a murine menopause model. Infect Immun. 2013;81:733-9.

26. Tincello DG, Taylor AH, Spurling SM, Bell SC. Receptor isoforms that mediate estrogen and progestagen action in the female lower urinary tract. J Urol. 2009;181:1474-82.

27. Lu M, Li JR, Alvarez-Lugo L, Li Y, Yu S, Li X, Shi B, Chai TC. Lipopolysaccharide stimulates BK channel activity in bladder umbrella cells. Am J Phys Cell Physiol. 2018;314:C643-53.

28. Papavlassopoulos M, Stamme C, Thon L, Adam D, Hillemann D, Seydel U, Schromm AB. MaxiK blockade selectively inhibits the lipopolysaccharideinduced I kappa B-alpha /NF-kappa B signaling pathway in macrophages. J Immunol. 2006;177:4086-93.

29. Li XT, Qiu XY. 17beta-estradiol upregulated expression of alpha and beta subunits of larger-conductance calcium-activated $\mathrm{K}(+)$ channels (BK) via estrogen receptor beta. J Mol Neurosci. 2015;56:799-807.

30. Acevedo-Alvarez M, Yeh J, Alvarez-Lugo L, Lu M, Sukumar N, Hill WG, Chai TC. Mouse urothelial genes associated with voiding behavior changes after ovariectomy and bladder lipopolysaccharide exposure. Neurourol Urodyn. 2018. https://doi.org/10.1002/nau.23592.

31. Aminu S. Trigonalgia: an overlooked cause of bladder pain. Afr J Urol. 2015; 21:244-5.

32. Shah AP, Mevcha A, Wilby D, Alatsatianos A, Hardman JC, Jacques S, Wilton JC. Continence and micturition: an anatomical basis. Clin Anat. 2014;27:1275-83.

33. Yucel S, Baskin LS. An anatomical description of the male and female urethral sphincter complex. J Urol. 2004;171:1890-7.

34. Oswald J, Heidegger I, Steiner E, Brenner E, Rennau ML, Pichler R, Becker T, Loidl W, Horninger W, Fritsch H. Gender-related fetal development of the internal urethral sphincter. Urology. 2013;82:1410-5.

35. Gilpin S, Gosling J. Smooth muscle in the wall of the developing human urinary bladder and urethra. J Anat. 1983;137:503.

36. Corton MM. Normal anatomy of the pelvis and pelvic floor. In: Female pelvic medicine and reconstructive surgery, clinical practice and surgical atlas. Philadelphia: McGraw-Hill Education; 2013. p. 31-4.

37. Wein AJ, Kavoussi LR, Partin AW, Peters CA, editors. Campbell-Walsh urology. 11th ed. Philadelphia: Elsevier; 2016.

38. Keegan KA, Nanigian DK, Stone AR. Female urethral stricture disease. Curr Urol Rep. 2008;9:419-23.

39. Cohen RJ, Garrett K, Golding JL, Thomas RB, McNeal JE. Epithelial differentiation of the lower urinary tract with recognition of the minor prostatic glands. Hum Pathol. 2002;33:905-9.

40. DeLancey JO. Correlative study of paraurethral anatomy. Obstet Gynecol. 1986;68:91-7.
41. Haab F, Sebe P, Mondet F, Ciofu C. Functional anatomy of the bladder and urethra in females. In: Corcos J, Schick E, editors. The urinary sphincter. Boca Raton: Taylor \& Francis Group; 2001. p. 15-24.

42. Drake MJ, Fry CH, Eyden B. Structural characterization of myofibroblasts in the bladder. BJU Int. 2006;97:29-32.

43. Baggish MS, Karram MM. Atlas of pelvic anatomy and gynecologic surgery. Philadelphia: Elsevier/Saunders; 2011.

44. Morita T, Latifpour J, O'Hollaren B, Wheeler MA, Weiss RM. Sex differences in function and distribution of alpha 1- and alpha 2-adrenoceptors in rabbit urethra. Am J Phys. 1987;252:F1124-8.

45. Alexandre EC, de Oliveira MG, Campos R, Kiguti LR, Calmasini FB, Silva FH, Grant AD, Yoshimura N, Antunes E. How important is the alpha1adrenoceptor in primate and rodent proximal urethra? Sex differences in the contribution of alpha1-adrenoceptor to urethral contractility. Am J Physiol Ren Physiol. 2017;312:F1026-34.

46. Jin ZW, Abe H, Hinata N, Li XW, Murakami G, Rodriguez-Vazquez JF. Descent of mesonephric duct to the final position of the vas deferens in human embryo and fetus. Anat Cell Biol. 2016;49:231-40.

47. Downing K. Biochemistry and ultrastructure of pelvic floor tissues and organs. In: Biomechanics of the female pelvic floor: Elsevier; 2016. p. 181-208.

48. Frontera WR, Ochala J. Skeletal muscle: a brief review of structure and function. Calcif Tissue Int. 2015;96:183-95.

49. Dixon J, Gosling J. Structure and innervation in the human. In: The physiology of the lower urinary tract. London: Springer; 1987. p. 3-22.

50. Gosling JA, Dixon JS, Critchley HO, Thompson SA. A comparative study of the human external sphincter and periurethral levator ani muscles. $\mathrm{Br} J$ Urol. 1981:53:35-41.

51. Praud C, Sebe P, Mondet F, Sebille A. The striated urethral sphincter in female rats. Anat Embryol (Berl). 2003;207:169-75.

52. Lim SH, Wang TJ, Tseng GF, Lee YF, Huang YS, Chen JR, Cheng CL. The distribution of muscles fibers and their types in the female rat urethra: cytoarchitecture and three-dimensional reconstruction. Anat Rec (Hoboken). 2013;296:1640-9.

53. Bierinx AS, Sebille $A$. The urethral striated sphincter in adult male rat. Anat Embryol (Berl). 2006;211:435-41.

54. Byers TJ, Kunkel LM, Watkins SC. The subcellular distribution of dystrophin in mouse skeletal, cardiac, and smooth muscle. J Cell Biol. 1991;115:411-21.

55. Russell B, Baumann M, Heidkamp MC, Svanborg A. Morphometry of the aging female rat urethra. Int Urogynecol J Pelvic Floor Dysfunct. 1996;7:30-6.

56. Buffini $\mathrm{M}, \mathrm{O}$ 'Halloran KD, O'Herlihy C, O'Connell R, Jones JF. Comparison of the contractile properties, oxidative capacities and fibre type profiles of the voluntary sphincters of continence in the rat. J Anat. 2010;217:187-95.

57. Chen SL, Wu M, Henderson JP, Hooton TM, Hibbing ME, Hultgren SJ, Gordon Jl. Genomic diversity and fitness of E. coli strains recovered from the intestinal and urinary tracts of women with recurrent urinary tract infection. Sci Transl Med. 2013;5:184ra160.

58. Smith $\mathrm{PG}$, Bradshaw S. Innervation of the proximal urethra of ovariectomized and estrogen-treated female rats. Histol Histopathol. 2004;19:1109-16.

59. Streng T, Santti R, Talo A. Similarities and differences in female and male rat voiding. Neurourol Urodyn. 2002;21:136-41.

60. Benoit G, Quillard J, Jardin A. Anatomical study of the infra-montanal urethra in man. J Urol. 1988;139:866-8.

61. Brading AF. The physiology of the mammalian urinary outflow tract. Exp Physiol. 1999;84:215-21.

62. Ho K, McMurray G, Brading A, Noble J. The human female striated urethral sphincter consists of a heterogeneous population of muscle fibres. $\mathrm{Br} J \mathrm{Urol}$. 1997;79:13.

63. Ho KM, McMurray G, Brading AF, Noble JG, Ny L, Andersson KE. Nitric oxide synthase in the heterogeneous population of intramural striated muscle fibres of the human membranous urethral sphincter. J Urol. 1998;159:1091-6.

64. Tokunaka S, Okamura K, Fujii H, Yachiku S. The proportions of fiber types in human external urethral sphincter: electrophoretic analysis of myosin. Urol Res. 1990;18:341-4.

65. Ho KM, Ny L, McMurray G, Andersson KE, Brading AF, Noble JG. Colocalization of carbon monoxide and nitric oxide synthesizing enzymes in the human urethral sphincter. J Urol. 1999;161:1968-72.

66. Bridgewater $M$, MacNeil HF, Brading AF. Regulation of tone in pig urethral smooth muscle. J Urol. 1993;150:223-8.

67. Persson K, Andersson KE. Non-adrenergic, non-cholinergic relaxation and levels of cyclic nucleotides in rabbit lower urinary tract. Eur J Pharmacol. 1994;268:159-67. 
68. Persson K, Igawa Y, Mattiasson A, Andersson KE. Effects of inhibition of the L-arginine/nitric oxide pathway in the rat lower urinary tract in vivo and in vitro. Br J Pharmacol. 1992;107:178-84.

69. Livingston BP. Anatomy and neural control of the lower urinary tract and pelvic floor. Top Geriatr Rehabil. 2016;32:280-94.

70. Ashton-Miller JA, DeLancey JO. Functional anatomy of the female pelvic floor. Ann N Y Acad Sci. 2007;1101:266-96.

71. Hull T, Zutshi M. Pathophysiology, diagnosis, and treatment of defecatory dysfunction. In: Female urology. 3rd ed. Philadelphia: Elsevier; 2008. p. 761-72.

72. Koelbl H, Strassegger H, Riss PA, Gruber H. Morphologic and functional aspects of pelvic floor muscles in patients with pelvic relaxation and genuine stress incontinence. Obstet Gynecol. 1989;74:789-95.

73. Jundt K, Kiening M, Fischer P, Bergauer F, Rauch E, Janni W, Peschers U, Dimpfl T. Is the histomorphological concept of the female pelvic floor and its changes due to age and vaginal delivery correct? Neurourol Urodyn. 2005;24:44-50.

74. Tobin C, Joubert Y. Testosterone-induced development of the rat levator ani muscle. Dev Biol. 1991;146:131-8.

75. Niel L, Willemsen KR, Volante SN, Monks DA. Sexual dimorphism and androgen regulation of satellite cell population in differentiating rat levator ani muscle. Dev Neurobiol. 2008;68:115-22.

76. Fritsch $\mathrm{H}$, Frohlich B. Development of the levator ani muscle in human fetuses. Early Hum Dev. 1994;37:15-25.

77. Foxman B. The epidemiology of urinary tract infection. Nat Rev Urol. 2010;7: 653-60.

78. Johnson CC. Definitions, classification, and clinical presentation of urinary tract infections. Med Clin North Am. 1991;75:241-52.

79. Ingersoll MA, Albert ML. From infection to immunotherapy: host immune responses to bacteria at the bladder mucosa. Mucosal Immunol. 2013;6:1041-53.

80. Miller E, Garcia T, Hultgren S, Oberhauser AF. The mechanical properties of E. coli type 1 pili measured by atomic force microscopy techniques. Biophys J. 2006:91:3848-56.

81. Parsons CL, Boychuk D, Jones S, Hurst R, Callahan H. Bladder surface glycosaminoglycans: an epithelial permeability barrier. J Urol. 1990;143:139-42.

82. Parsons CL, Greenspan C, Moore SW, Mulholland SG. Role of surface mucin in primary antibacterial defense of bladder. Urology. 1977;9:48-52.

83. Mora-Bau G, Platt AM, van Rooijen N, Randolph GJ, Albert ML, Ingersoll MA. Macrophages subvert adaptive immunity to urinary tract infection. PLoS Pathog. 2015;11:e1005044.

84. Engel DR, Maurer J, Tittel AP, Weisheit C, Cavlar T, Schumak B, Limmer A van Rooijen N, Trautwein C, Tacke F, Kurts C. CCR2 mediates homeostatic and inflammatory release of Gr1(high) monocytes from the bone marrow, but is dispensable for bladder infiltration in bacterial urinary tract infection. J Immunol. 2008;181:5579-86.

85. Godaly G, Hang L, Frendeus B, Svanborg C. Transepithelial neutrophil migration is CXCR1 dependent in vitro and is defective in IL-8 receptor knockout mice. J Immunol. 2000;165:5287-94.

86. Chan CY, St John AL, Abraham SN. Mast cell interleukin-10 drives localized tolerance in chronic bladder infection. Immunity. 2013;38:349-59.

87. Christmas TJ. Lymphocyte sub-populations in the bladder wall in normal bladder, bacterial cystitis and interstitial cystitis. Br J Urol. 1994;73:508-15.

88. Grist M, Chakraborty J. Identification of a mucin layer in the urinary bladder. Urology. 1994:44:26-33.

89. Ackerman $\mathrm{AL}$, Underhill $\mathrm{DM}$. The mycobiome of the human urinary tract: potential roles for fungi in urology. Ann Transl Med. 2017;5:31.

90. Fouts DE, Pieper R, Szpakowski S, Pohl H, Knoblach S, Suh MJ, Huang ST, Ljungberg I, Sprague BM, Lucas SK, et al. Integrated next-generation sequencing of $16 \mathrm{~S}$ rDNA and metaproteomics differentiate the healthy urine microbiome from asymptomatic bacteriuria in neuropathic bladder associated with spinal cord injury. J Transl Med. 2012;10:174.

91. Hilt EE, McKinley K, Pearce MM, Rosenfeld AB, Zilliox MJ, Mueller ER, Brubaker L, Gai X, Wolfe AJ, Schreckenberger PC. Urine is not sterile: use of enhanced urine culture techniques to detect resident bacterial flora in the adult female bladder. J Clin Microbiol. 2014;52:871-6.

92. Khasriya R, Sathiananthamoorthy S, Ismail S, Kelsey M, Wilson M, Rohn JL, Malone-Lee J. Spectrum of bacterial colonization associated with urothelial cells from patients with chronic lower urinary tract symptoms. J Clin Microbiol. 2013;51:2054-62.

93. Miller-Ensminger T, Garretto A, Brenner J, Thomas-White K, Zambom A, Wolfe AJ, Putonti C. Bacteriophages of the urinary microbiome. J Bacteriol. 2018;200:e00738-17.
94. Santiago-Rodriguez TM, Fornaciari G, Luciani S, Dowd SE, Toranzos GA, Marota I, Cano RJ. Gut microbiome of an 11th century AD Pre-Columbian Andean mummy. PLoS One. 2015;10:e0138135.

95. Wolfe AJ, Toh E, Shibata N, Rong R, Kenton K, Fitzgerald M, Mueller ER, Schreckenberger P, Dong Q, Nelson DE, Brubaker L. Evidence of uncultivated bacteria in the adult female bladder. J Clin Microbiol. 2012;50: 1376-83.

96. Brubaker L, Nager CW, Richter HE, Visco A, Nygaard I, Barber MD, Schaffer J, Meikle S, Wallace D, Shibata N, Wolfe AJ. Urinary bacteria in adult women with urgency urinary incontinence. Int Urogynecol J. 2014;25:1179-84.

97. Pearce MM, Zilliox MJ, Rosenfeld AB, Thomas-White KJ, Richter HE, Nager CW, Visco AG, Nygaard IE, Barber MD, Schaffer J, et al. The female urinary microbiome in urgency urinary incontinence. Am J Obstet Gynecol. 2015;213:347.e1-11.

98. Karstens L, Asquith M, Davin S, Stauffer P, Fair D, Gregory WT, Rosenbaum JT, McWeeney SK, Nardos R. Does the urinary microbiome play a role in urgency urinary incontinence and its severity? Front Cell Infect Microbiol. 2016;6:78.

99. Pearce MM, Hilt EE, Rosenfeld AB, Zilliox MJ, Thomas-White K, Fok C, Kliethermes S, Schreckenberger PC, Brubaker L, Gai X, Wolfe AJ. The female urinary microbiome: a comparison of women with and without urgency urinary incontinence. MBio. 2014;5:e01283-14.

100. Thomas-White KJ, Hilt EE, Fok C, Pearce MM, Mueller ER, Kliethermes S, Jacobs K, Zilliox MJ, Brincat C, Price TK, et al. Incontinence medication response relates to the female urinary microbiota. Int Urogynecol J. 2016;27:723-33.

101. Brubaker $L$, Wolfe A. The urinary microbiota: a paradigm shift for bladder disorders? Curr Opin Obstet Gynecol. 2016;28:407-12.

102. Finucane TE. "Urinary tract infection" - requiem for a heavyweight. J Am Geriatr Soc. 2017:65:1650-5.

103. Mueller ER, Wolfe AJ, Brubaker L. Female urinary microbiota. Curr Opin Urol. 2017:27:282-6.

104. Price TK, Dune T, Hilt EE, Thomas-White KJ, Kliethermes S, Brincat C, Brubaker L, Wolfe AJ, Mueller ER, Schreckenberger PC. The clinical urine culture: enhanced techniques improve detection of clinically relevant microorganisms. J Clin Microbiol. 2016;54:1216-22.

105. Price TK, Hilt EE, Dune TJ, Mueller ER, Wolfe AJ, Brubaker L. Urine trouble: should we think differently about UTI? Int Urogynecol J. 2018;29:205-10.

106. Jacobs KM, Thomas-White KJ, Hilt EE, Wolfe AJ, Waters TP. Microorganisms identified in the maternal bladder: discovery of the maternal bladder microbiota. AJP Rep. 2017;7:e188-96.

107. Blakeman PJ, Hilton P, Bulmer JN. Oestrogen and progesterone receptor expression in the female lower urinary tract, with reference to oestrogen status. BJU Int. 2000;86:32-8.

108. Celayir S. Is there a "bladder sex"? The relation of different sex hormones and sex hormone receptors in bladder in childhood. Med Hypotheses. 2002; 59:186-90.

109. Keast JR, Saunders RJ. Testosterone has potent, selective effects on the morphology of pelvic autonomic neurons which control the bladder, lower bowel and internal reproductive organs of the male rat. Neuroscience. 1998; 85:543-56.

110. Makela S, Strauss L, Kuiper G, Valve E, Salmi S, Santti R, Gustafsson JA. Differential expression of estrogen receptors alpha and beta in adult rat accessory sex glands and lower urinary tract. Mol Cell Endocrinol. 2000;170:219-29.

111. McKenna KE, Nadelhaft I. The organization of the pudendal nerve in the male and female rat. J Comp Neurol. 1986;248:532-49.

112. Savolainen S, Santti R, Streng T, Gustafsson JA, Harkonen P, Makela S. Sex specific expression of progesterone receptor in mouse lower urinary tract. Mol Cell Endocrinol. 2005;230:17-21.

113. Bødker A, Balslev E, Juul BR, Stimpel $H$, Meyhoff $H-H$, Hedlund $H$, Hedlund $P$, Iversen $\mathrm{H}-\mathrm{G}$, Andersson K-E. Estrogen receptors in the human male bladder, prostatic urethra, and prostate: an immunohistochemical and biochemical study. Scand J Urol Nephrol. 1995;29:161-5.

114. Kuiper G, Enmark E, Pelto-Huikko M, Nilsson S, Gustafsson J-A. Cloning of a novel receptor expressed in rat prostate and ovary. Proc Natl Acad Sci U S A. 1996;93:5925-30.

115. Yu Y, Shen Z, Zhou X, Chen S. Effects of steroid hormones on morphology and vascular endothelial growth factor expression in female bladder. Urology. 2009;73:1210-7.

116. Purves-Tyson TD, Arshi MS, Handelsman DJ, Cheng Y, Keast JR. Androgen and estrogen receptor-mediated mechanisms of testosterone action in male rat pelvic autonomic ganglia. Neuroscience. 2007;148:92-104.

117. Celayir S, Ilçe Z, Büyükünal S. Is there a bladder sex? The effects of sex hormones to female rabbit bladder I: an experimental study. BJU Int. 2000;85:40. 
118. Celayir S. Effects of different sex hormones on male rabbit urodynamics: an experimental study. Horm Res. 2003;60:215-20.

119. Robinson D, Toozs-Hobson P, Cardozo L. The effect of hormones on the lower urinary tract. Menopause Int. 2013;19:155-62.

120. Van Geelen JM, Doesburg WH, Thomas CM, Martin CB Jr. Urodynamic studies in the normal menstrual cycle: the relationship between hormonal changes during the menstrual cycle and the urethral pressure profile. Am J Obstet Gynecol. 1981;141:384-92.

121. Boorjian S, Ugras S, Mongan NP, Gudas L, You X, Tickoo SK, Scherr DS. Androgen receptor expression is inversely correlated with pathologic tumor stage in bladder cancer. Urology. 2004;64:383-8.

122. Miyamoto $H$, Yang Z, Chen YT, Ishiguro H, Uemura H, Kubota Y, Nagashima Y, Chang YJ, Hu YC, Tsai MY, et al. Promotion of bladder cancer development and progression by androgen receptor signals. J Natl Cancer Inst. 2007;99:558-68.

123. Miyamoto H, Yao JL, Chaux A, Zheng Y, Hsu I, Izumi K, Chang C, Messing EM, Netto GJ, Yeh S. Expression of androgen and oestrogen receptors and its prognostic significance in urothelial neoplasm of the urinary bladder. BJU Int. 2012;109:1716-26.

124. Teng J, Wang ZY, Jarrard DF, Bjorling DE. Roles of estrogen receptor alpha and beta in modulating urothelial cell proliferation. Endocr Relat Cancer. 2008:15:351-64

125. Mir C, Shariat SF, van der Kwast TH, Ashfaq R, Lotan Y, Evans A, Skeldon S, Hanna S, Vajpeyi R, Kuk C, et al. Loss of androgen receptor expression is not associated with pathological stage, grade, gender or outcome in bladder cancer: a large multi-institutional study. BJU Int. 2011;108:24-30.

126. Levin RM, Shofer FS, Wein AJ. Estrogen-induced alterations in the autonomic responses of the rabbit urinary bladder. J Pharmacol Exp Ther. 1980;215:614-8.

127. Bajic $P$, Van Kuiken ME, Burge BK, Kirshenbaum EJ, Joyce CJ, Wolfe AJ, Branch JD, Bresler L, Farooq AV. The male bladder microbiome relates to lower urinary tract symptoms. Eur Urol Focus. 2018. https://doi.org/10.1016/ j.euf.2018.08.001 [Epub ahead of print] PMID: 301434711.

Ready to submit your research? Choose BMC and benefit from:

- fast, convenient online submission

- thorough peer review by experienced researchers in your field

- rapid publication on acceptance

- support for research data, including large and complex data types

- gold Open Access which fosters wider collaboration and increased citations

- maximum visibility for your research: over $100 \mathrm{M}$ website views per year

At $\mathrm{BMC}$, research is always in progress.

Learn more biomedcentral.com/submissions 